\title{
One of the flint tool production strategies based on erratic flint, exemplified by Mesolithic materials from the Dobryń Mały 7 site (central-eastern Poland)
}

\author{
Piotr Mączyński \\ Institute of Archaeology, University of Rzeszów. Śnieżyńskiego st. 5, 20-706 Lublin, Poland. \\ Email: archeolublin@gmail.com
}

\begin{abstract}
:
Baltic erratic flint is one of the most important stone raw materials used in the area of the Polish lowlands. Since its first description published in 1920 by Stefan Krukowski, generations of researchers continue to investigate the topic through studies on the characteristics of this raw material as well as processing successive collections of artefacts made of this flint. In this paper special attention is drawn to production strategy based on this type of raw material typical for Mesolithic inventories. It involves the use of natural flint chunks resulting from shattering of frost weathered concretions. With respect to the materials recovered from the 7 in Dobryn Mały site, it is reflected mainly in the production of core tools. However, to a much lesser extent, it is also present in the process of raw material selection for the production of blade and flake blanks.
\end{abstract}

Keywords: raw material; Baltic erratic flint; stone tool production; core axe blades; Mesolithic

\section{Introduction}

Erratic flint present in glacial sediments is encountered in many areas of Polish lands. Location of its deposits in the near-surface zone render this material one of the most frequently used siliceous rocks in the prehistoric period (Cyrek 1983). Unfortunately, being affected by the adverse effects of glacial transportation and weathering, concretions of this raw material are of poor quality (Ginter \& Kozłowski 1990). This condition may significantly impede proper core reduction or even make it impossible. Despite this hindrance, the shape and the form of fractured flint blocks, in some cases could have been used in manufacture of tools. In this paper I would like to draw attention to some issues related to flint production of Mesolithic population, which was based on the usage of erratic flint. My considerations will be based on source materials from multicultural site Dobryń Mały 7.

The afore mentioned site is located in the central-eastern part of Poland (Fig. 1), within the area of the Lublin Polesie macroregion. The site occupies a wooded, sandy elevation of an area of less than 2 hectares, which is believed to be an outcome of terrain forming activities of

Published by the School of History, Classics and Archaeology, University of Edinburgh ISSN: 2055-0472. URL: http://journals.ed.ac.uk/lithicstudies/

This work is licensed under a Creative Commons Attribution 2.5 UK: Scotland License. 
the Warta glaciation (Nitychoruk \& Gałązka 2000; Kondracki 2002). Its surface rises circa 2 $\mathrm{m}$ above the valley of a small watercourse called Młyniec extending to the east.

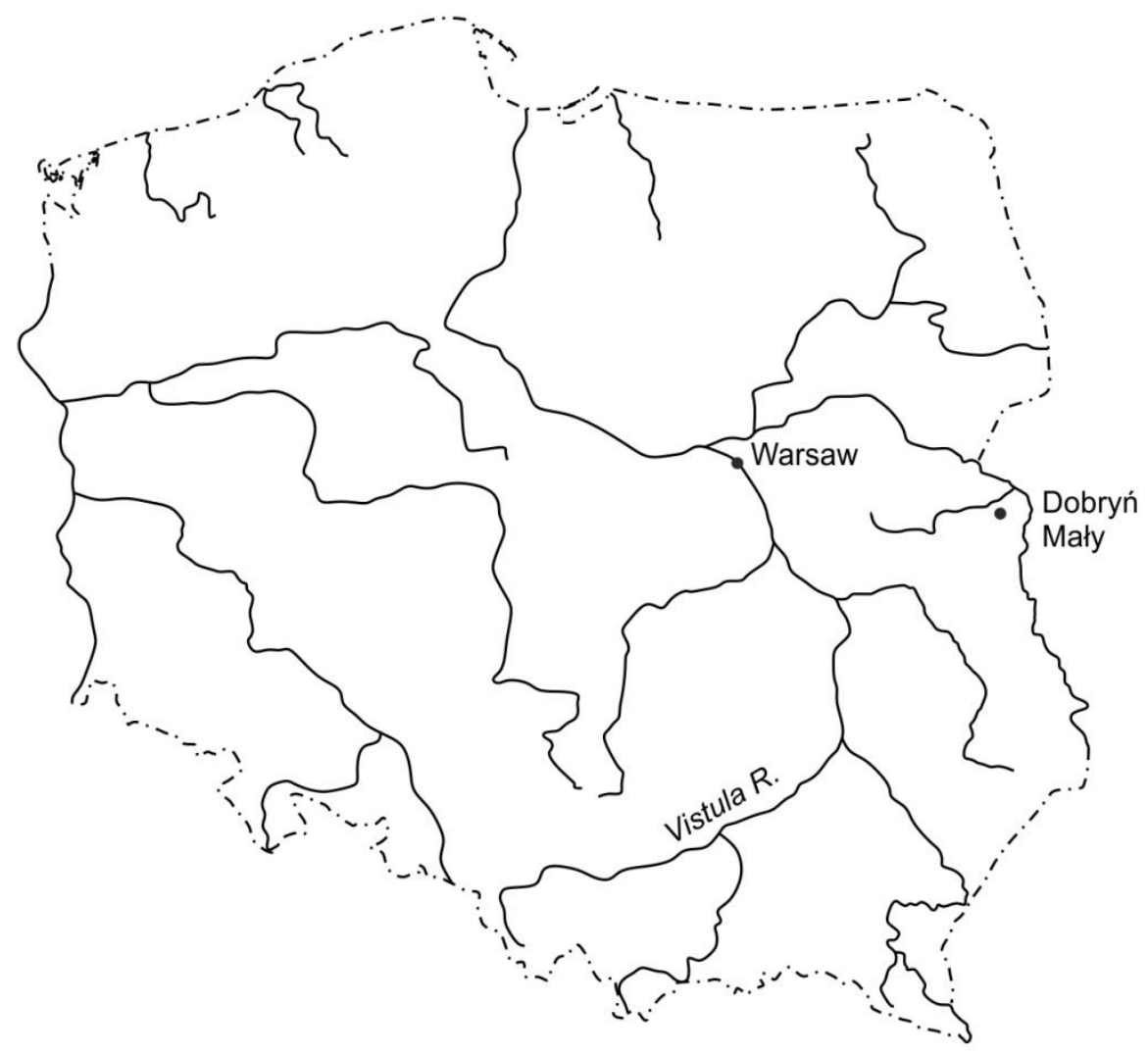

Figure 1. Location of the site Dobryń Mały 7.

The site was identified for the first time during surface survey performed in April 1984 under the project of the Polish Archaeological Record (Archeologiczne Zdjęcie Polski) by professor Wojciech Nowakowski, PhD (Bienia \& Żółkowski 1993). The first excavations began in 1993 under the supervision of M. Bienia and S. Żółkowski. During the six-year-long excavation campaign carried out on the site a number of layers and archaeological features with complex chronology were identified. Large series of the settlement phases were identified, dated to the Stone Age, Bronze Age and Iron Age, and more precisely to the younger pre-Roman period and the early Middle Ages (Bienia \& Żółkowski 1993; Bienia \& Żółkowski 1995; Bienia 2003; Bienia 2006).

\section{Source materials and methods}

The majority of the considerations presented in this paper are based on the material discovered in excavation unit No. 45. The chronology of these finds should be correlated with the late Mesolithic period, that is, with the 4th millennium BC (Więckowska 1985; Kozłowski 1989; Libera 1995; Kozłowski 1996). The flint assemblage recovered here occurred in a concentration whose diameter is 3 to 4 meters. Due to the above mentioned diversity and continuity of settlement on the discussed site, the flint concentration was partially destroyed by two chronologically subsequent features dated to the younger pre-Roman period (Bienia 2006). The assemblage recovered contains only 184 artefacts. All forms (excluding burnt products) were made of erratic flint. In order to obtain maximum information from the discussed inventory during its processing, re-fitting method was used. It resulted in establishing 11 refitted blocks containing $14 \%$ of the total material unearthed in the discussed 
clusters (Mączyński in press). In addition to these, considerations are also based on materials from a collection gathered during surface surveys, as well as ones discovered in feature number 41, in which a small number of final Palaeolithic finds appeared in addition to the Mesolithic material (Bienia \& Żółkowski 1995). Having in mind the heterogeneous character of this collection and in spite of it, it was decided to include 4 specimens of core axes and their semi-products.

\section{Results}

\subsection{Raw material characteristics}

Erratic flint typically occurs in a form of oval or more irregularly shaped concretions, with a diameter up to a dozen or so centimetres. The colour of the flint body is pale grey, pale grey-blue or bluish-blackish, with numerous discolourations and light spots in it. The surface of concretions is covered with thin layer of white cortex. The lumps of flint usually demonstrate poor state of preservation. On their outer surfaces there are visible signs of damage in the form of worn cortex, crushed spots and some negatives of uncontrolled flaking caused by prolonged glacial transportation (Krukowski 1920; Kozłowski 1989). Due to the extended deposition in the near-surface zone the lumps of this raw material were exposed to strong weathering processes (Ginter \& Kozłowski 1990), which caused extensive frost cracking within the flint body that led to shattering of concretion or causing its angular disintegration at first attempts of obtaining blanks from seemingly pristine-looking lump of flint.

It seems that the raw material utilized on this site originated from the closest vicinity of the dune. This supposition is supported by the fact that the current terrain configuration is created mainly by glacial deposits rich in erratic materials (Nitychoruk \& Gałązka 2000). However, an attempt to locate their outcrops seems to be impossible to achieve at the current stage of the research.

\subsection{Core Tools}

It seems that the unearthed collection of core tools is the most interesting example of adaptation of chunks that are an outcome of frost shattering of flint concretions. In total 7 artefacts made in this technique were identified. Most of them are specimens of core axe blades ( 4 pieces) and their semi-products ( 2 pieces). The last form is a single specimen of an endscraper.

Small extent of work completed on some of them allows to describe the shape of the raw material, which has been selected for the production of the tools. In the case of most of the axe blades, the outline of the flint chunks was subtriangular (Fig. $2: 1 ; 4: 1$ ) or close to a shape of tall trapezoid (Fig. 2: 3, 3:1). It has to be pointed out that the preferred forms were chunks with flat sides, resulting from frost cracking, coinciding with each other and thus forming a sharp edge. This edge was usually chosen to be the cutting edge (additionally corrected with a retouch). Such instance was observed in the case of five forms (Fig. 2: 1, 3, 4; 3: 1; 4: 1). Majority of the specimens have a small amount of processing. It is usually limited to correction of certain sections of surfaces of the sides (axe blade cheeks), as well as butts and cutting edges, which in every case were formed by a series of removals from the front of the tool. In the case of the two artefacts subject to the analysis, an axe blade (Fig. 2: 3) and a semi-product of an axe blade (Fig. 2: 1), the forming was limited only to a retouch of the edge selected for the cutting edge. In the entire set these are the examples of tools with the least advanced treatment. While the interpretation of the first artefact does not seem to cause any doubts, in the case of the second form its interpretation seems to be problematic due to 
very limited treatment in the form of few irregular negatives visible on the edge, which is identified as the cutting edge. However, taking into account its morphology and size, which are similar to the other described forms, it was decided to include this specimen among semiproducts of axe blades.
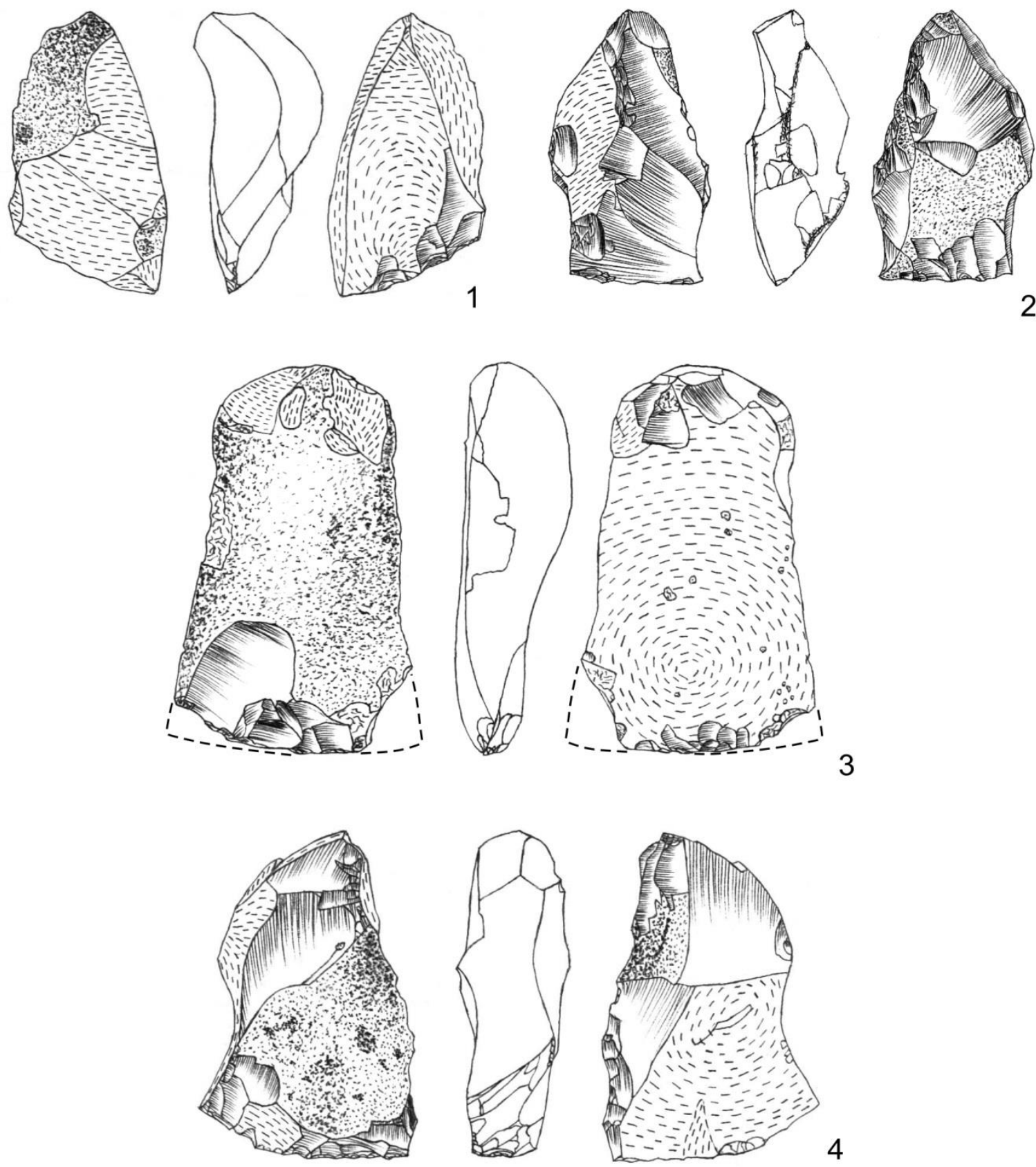

Figure 2. Core tools. 1 - semi-products of core axe blade (?); 2-4 - core axe blades. Drawn by P. Mączyński.

The last product is an endscraper. A natural flint chunk was used for its production. The shape of the chunk is sub-rhomboidal and the treatment completed on it was limited to a retouch of the working edge (Fig. 3: 2). 

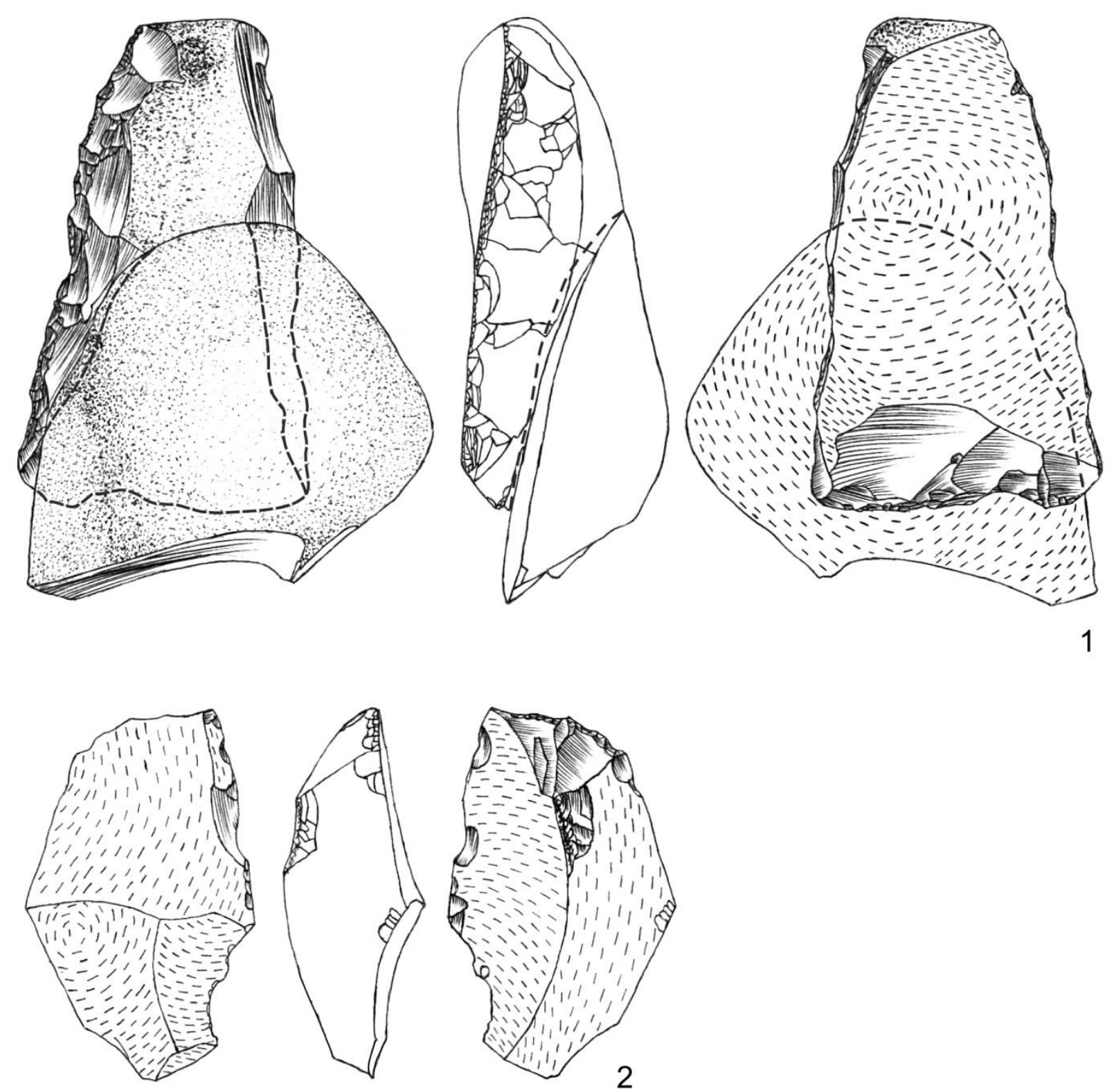

Figure 3. 1 - refit of a core axe blade with a natural chunk; 2 - endscraper. Drawn by P. Mączyński.

\subsection{Tool production debitage}

Forms interpreted as debitage associated with production of tools were scarce in the discussed assemblage. The only one of them is a flake that can be re-fitted into a semi-product of a core axe blade. This specimen comes from a stage of preparation of the cutting edge. It was removed perpendicularly to the edge and is one of a series of at least six (?) flakes coming from this stage of artefact processing (Fig. 4: 1).

Analysis of the negatives visible on the tools indicates that in most cases production debitage should include flakes and scales, whose dorsal side will have natural surface or, in the case of more advanced treatment, will be covered with negatives. At the current state of the research, it seems that this group of finds do not have the characteristics that would allow to differentiate them from other debitage products. As shown by the above example, the prospect of separation of production debitage is possible only in case of obtaining refits. 

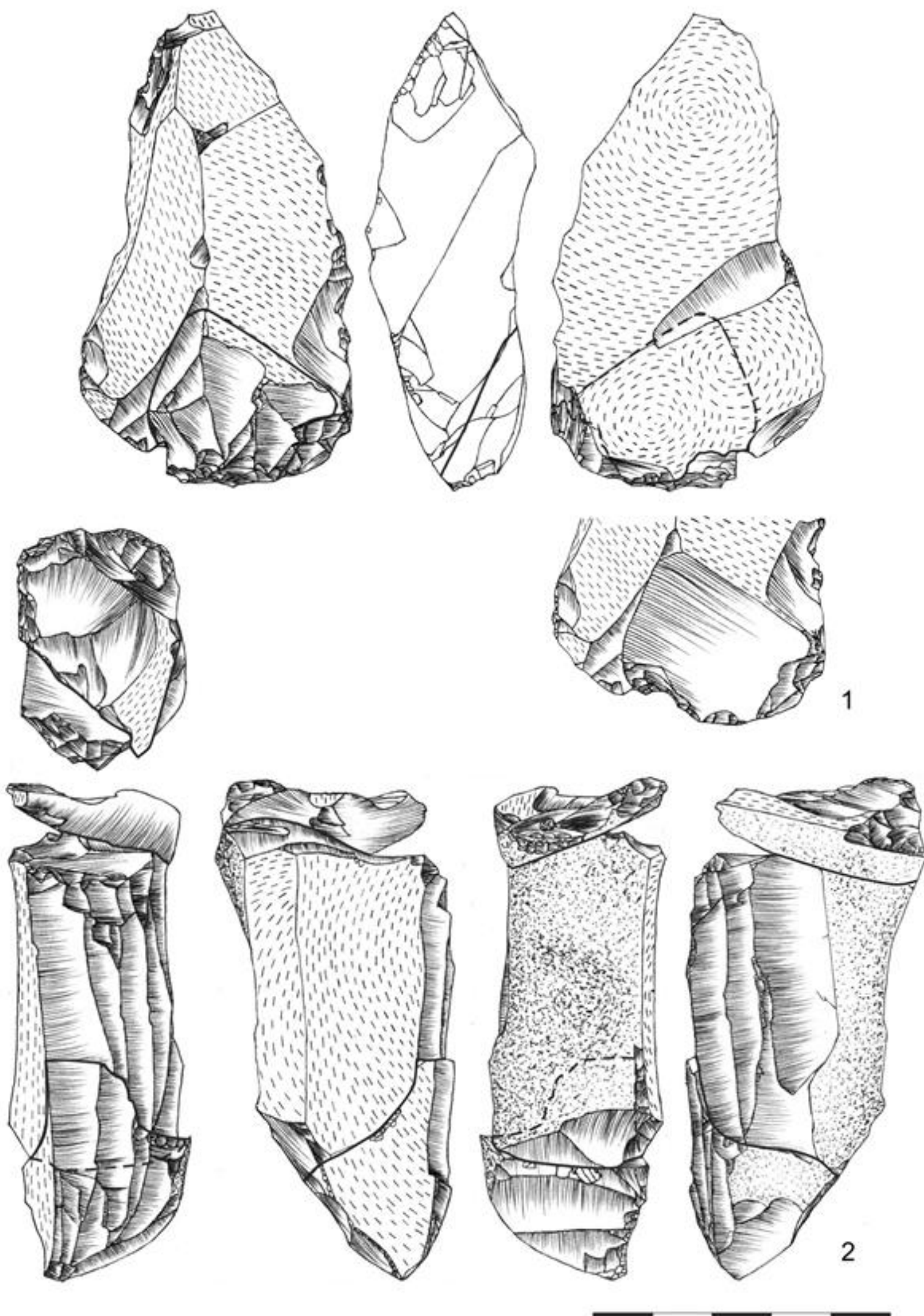

Figure 4.1 - refit of a semi-product of a core axe blade with a flake forming the cutting edge; 2 - refit of a blade core with a flake forming the striking platform and a fragment of an overstruck blade from single platform core. Drawn by P. Mączyński. 


\subsection{Cores}

Strategy of selecting raw material with appropriate parameters is not limited solely to the production of core tools. It was also observed in the case of core reduction process aimed at obtaining flake and blade blanks. In the vast majority of cases, the degree of reduction of the cores does not allow for the reconstruction of the initial shape of the raw material. However, as indicated by the analysis of preserved cores and semi-products, on which natural surfaces are still visible, it might be observed that a lot of raw material concretions had flat natural surface that have been chosen as striking platforms or flaking faces. One of the more interesting artefacts showing an example of such adaptation is the refitted block visible in the figure number 4: 2. It is a refit of a blade core with a flake forming the striking platform and an overstruck blade from single platform core. The preserved shape of the refitted block allows partial reconstruction of the shape of the raw material. It appears that the original form of the chunk was hexagonal with regular shape and of the initial height and width of approximately 110 and 28 millimetres, respectively. Because of the advanced reduction of the core it is impossible to determine its thickness (at the present it is $34 \mathrm{~mm}$ ). Natural surfaces of the raw material (cortical and caused by frost shattering) were selected as the side walls and the back of the core. Such selection of raw material allowed significant minimization of prereduction preparation, restricting it to preparation of the striking platform, making small adjustments of other surfaces and, most probably, also preparation of flaking face (but this last step is currently impossible to reconstruct). As a result the majority of the sides were natural surfaces. It seems that the described example of raw material selection greatly facilitated processing, reduced the risk of error during the preparation stage, and above all prevented excessive loss of the raw material weight (Mączyński in press).

\section{Conclusions}

As a result of the technological analysis of the flint artefacts recovered from the site Dobryń Mały 7, their production technique was identified. It was based on flint chunks, which were an outcome of frost shatter. All of the analysed core axe blades and the single specimen of endscraper were made facilitating this technique. There is no doubt, the main concept of the flint tools production was based on the exploitation of blade and flake cores. Indeed, blade and flake blanks were the primary semi-products from which the prevailing majority of tools discovered on the site were made (Mączyński in press). In contrast, production of tools from chunks was a sporadic activity. It seems that it had a purely pragmatic nature and resulted from the ease of turning selected chunks of adequate shape into tools. This is evident in the case of selecting chunks with sides coinciding with one another and thus forming a straight edge, which with appropriate retouch could have been adapted as a cutting edge (Fig. 2: 1, 3, 4; $3: 1 ; 4: 1)$. In addition, their natural shape allowed to limit their preparation merely to correction of certain surfaces. Additionally, it seems that the size of the tools was also important since their production required use of raw materials of relatively large dimension.

Technical qualities of frost cracked flint chunks were also facilitated in the classical model of flint knapping based on exploitation of blade and flake cores. In most of the cases, the significant degree of reduction of the cores does not allow to reconstruct the shape of the semi-product. A good example of adaptation of frost cracked concretions as material for future cores is represented by the refitted block as shown in figure no. 4: 2 . Selection of raw material with the shape of regular hexagonal block allowed for a significant simplification of the core preparation process. Also preserved are flat surfaces of chunks that were selected as striking platforms or flaking faces in numerous cases of the remaining cores, mainly flake ones, discovered on the site. 
The phenomenon of the use of flint chunks does not seem to be isolated. It is an example of adapting technology to the specific characteristics of flint raw materials available within procurement range. Similar observations regarding the use of natural chunks as the material used for production of tools have already been made in the context of other Mesolithic finds. Particular attention should be paid to the site in Wistka Szlachecka, where a series of dozen or so tools were made from frost shattered chunks (Wąs 2005). Beyond doubt it seems that the observed strategy of flint production was determined by the environmental conditions. Growth of forests during the Holocene significantly impeded access to deposits of good quality raw materials and probably constrained the mobility of hunter gatherer population (Clark 1967) forcing them to use raw materials of inferior parameters. However, as the presented consideration proves Mesolithic population managed to adapt well to the existing situation.

\section{References}

Bienia, M. 2003, Czasy prehistoryczne. In: Pólnocna Lubelszczyzna od pradziejów po wczesne średniowiecze, (Banasiewicz-Szykuła, E., Ed.), Skarby z Przeszłości 5, Lublin: p. 23-72. (in Polish) ("Prehistoric Times").

Bienia, M. 2006, Dobryń Mały stan. 7 gm. Zalesie, woj. lubelskie AZP 60-89 stan. 22 Osada i cmentarzysko wielokulturowe epoka kamienia, młodszy okres przedrzymski (kultury jastorfska i przeworska) wczesne średniowiecze. Dokumentacja polowa z ratowniczych badań wykopaliskowych przeprowadzonych w dniach 29 sierpnia - 12 września 2006 roku. Maszynopis przechowywany w archiwum Wojewódzkiego Konserwatora Zabytków w Lublinie Delegatura w Białej Podlaskiej: p. 26-27. (in Polish) ("Dobryń Mały site 7, commune of Zalesie, Lublin province, AZP(PAR) 60-89 site 22 Settlement and multicultural burial ground of the Stone Age, younger pre-Roman period (Jastorf culture and Przeworsk culture), early Middle Ages. Field documentation of rescue excavations carried out between August 29 - September 12, 2006").

Bienia, M., \& Żółkowski, S. 1993, Dobryń Mały st. VII gm. Zalesie, woj. Biała Podlaska. Badania wykopaliskowe 1993. Maszynopis przechowywany w archiwum Wojewódzkiego Konserwatora Zabytków w Lublinie Delegatura w Białej Podlaskiej: p. 1-4. (in Polish) ("Dobryń Mały site VII, commune of Zalesie, province of Biała Podlaska. Excavations in 1993").

Bienia, M., \& Żółkowski, S. 1995, Dobryń Mały st. VII gm. Zalesie, woj. Biała Podlaska. Badania wykopaliskowe 1995. Maszynopis przechowywany w archiwum Muzeum Południowego Podlasia w Białej Podlaskiej: p. 1-5. (in Polish) ("Dobryń Mały site VII, commune of Zalesie, province of Biała Podlaska. Excavations in 1995”).

Clark, G. 1967, The Stone Age Hunters, Publishing House "McGraw-Hill”, London, 92 p.

Cyrek, K. 1983, Surowce krzemienne w mezolicie dorzeczy Wisły i górnej Warty. In: Człowiek i środowisko w pradziejach, (Kozłowski, J.K., \& Kozłowski, S.K., Eds.), Polish Scientific Publishers, Warsaw: p. 106-113. (in Polish) ("Flint raw materials during the Mesolithic period in the Vistula and upper Warta basins").

Ginter, B., \& Kozłowski, S.K. 1990, Technika obróbki i typologia wyrobów kamiennych paleolitu, mezolitu i neolitu, Polish Scientific Publishers, Warsaw, 28 p. (in Polish) ("Processing technology and typology of stone artefacts from the Paleolithic, Mesolithic and Neolithic periods"). 
Kondracki, J. 2002, Geografia regionalna Polski. Polish Scientific Publishers, Warsaw, 291 p. (in Polish) ("Regional Geography of Poland").

Kozłowski, S.K. 1989, Mesolithic in Poland. A New Approach, Warsaw University Press, Warsaw, $246 \mathrm{p}$.

Kozłowski, S.K. 1996, Early Postglacial Adaptations in Poland and Central Europe (Mesolithic/Epipaleolithic). In: The Mesolithic. Colloquia of the XIII International Congress of Prehistoric and Protohistoric Sciences, Forli (Italia), 8-14 September 1996, (Kozłowski, S.K., \& Tozzi, C., Eds.), Publishing House “A.B.A. C.O.”, Forli: p. 149-162.

Krukowski, S. 1920, Pierwociny krzemieniarskie górnictwa, transportu i handlu w holocenie Polski. Wiadomości Archeologiczne 5: 185-206. (in Polish) ("Origins of flint mining, transportation and trade in the Holocene on Polish territory").

Libera, J. 1995, Późny paleolit i mezolit środkowowschodniej Polski. Część pierwsza. Analiza. Maria Curie-Skłodowska University Press, Lublin: 48 p. (in Polish) ("The late Paleolithic and Mesolithic periods in central-eastern Poland. Part One. The Analysis").

Mączyński, P. in press, Wykorzystanie krzemienia narzutowego przez społeczności mezolityczne na stanowisku w Dobryniu Małym 7, pow. bialski, na przykładzie wykopu numer 45. Studia nad Gospodarka Surowcami Krzemiennymi w Pradziejach 8: in press. (in Polish) ("Use of erratic flint by Mesolithic communities as exemplified by excavation unit no. 45 at the site Dobryń Mały 7, district of Bielsk Podlaski”).

Nitychoruk, J., \& Gałązka, D. 2000, Szczegółowa mapa geologiczna Polski 1:50 000, arkusz 569-Rokitno (N-34-143-D). PIG, Warsaw. (in Polish) ("Detailed geological map of Poland 1:50 000, sheet 569-Rokitno").

Wąs, M. 2005, Technologia krzemieniarstwa kultury janisławickiej, Monografie Instytutu Archeologii Uniwersytetu Łódzkiego Vol. 3, Wydawnictwo Inicjał3, Łódź: p. 271. (in Polish) ("Flint technology of the Janislavice culture").

Więckowska, H. 1985, Osadnictwo późnopaleolityczne i mezolityczne nad Dolna Narwia, Polskie Badania Archeologiczne 24, Publishing House „Ossolineum”, Wrocław: 110 p. (in Polish) ("Lower Narew Late Palaeolithic and Mesolithic settlement"). 
